\title{
Evaluation of Heavy metals pollution around Kano municipal solid waste Dumpsites, Kano state, Nigeria
}

MZ Karkarna and Mujahid Ajah Matazu

Department of Environmental Management, Bayero University P.M.B 3011-Kano

Correspondence authors: mzkarkarna@ gmail.com

\begin{abstract}
The research was conducted to assess the level of heavy metals contamination using single and integrated pollution indices in soils around municipal solid waste dumpsites of Kano Metropolis, Kano State, Nigeria. Forty two soil samples were collected from seven municipal solid waste dumpsites of Kano metropolis using circular plot method. A stainless hand auger at a depth of (0 to 15) top soils and sub-surface soils $(15-30 \mathrm{~cm})$ depth were collected and analyzed with Flame atomic absorption spectrophotometer to determine the heavy metal concentration. The mean concentration $(\mathrm{mg} / \mathrm{kg})$ of heavy metals from the depth of $(15-30 \mathrm{~cm})$ were observed to follow a decreasing order $\mathrm{Pb}(7.71)>\mathrm{Zn}(0.50)>\mathrm{Ni}(0.45)>\mathrm{Cr}(0.31)>\mathrm{Cd}(0.025)$ while for surface soils $(0$ $15 \mathrm{~cm})$ the mean concentration were in the following order: $\mathrm{Pb}(1.77)>\mathrm{Ni}(0.49)>\mathrm{Zn}(0.30)>\mathrm{Cr}$ $(0.27)>C d(0.012)$. The results showed that calculated CF and Er recorded that investigated soil samples are uncontaminated with $\mathrm{Zn}, \mathrm{Pb}, \mathrm{Cd}, \mathrm{Cr}$ and $\mathrm{Pb}$ and $\mathrm{Ni}$. The pollution load index (PLI) was less than unity showing that there was minimum pollution in the studied dumpsite. The potential ecological risk showed that soil samples were in the class of low contaminated with the studied heavy metals. The results showed that concentrations of heavy metals of soil samples from dumpsites location at waste dumpsites of Kano Metropolis were within limits of European Union (2002) standards.
\end{abstract}

Keywords: Heavy metals, single and integrated pollution indices Kano, Municipal dumpsites,

\section{INTRODUCTION}

Solid wastes disposal in major cities of Nigeria in the last few decades has posed major environmental and public health problems (Dirisu et al, 2019). Most affected are those living adjacent the dumpsites due to the potential of the waste to pollute water, food sources, land, air and vegetation (Un-habitat, 2008). In Kano Metropolis and most developing cities in Africa where increase in population and industrial activities were being experienced mostly due urbanization and economic development, has led to indiscriminate dumping of wastes of various sources in and around any available large expanse of land either under fallow or abandoned by the land owners. Research carried out on lands close to dumpsites at Zaria city showed that soil around dumpsites is as well contaminated with heavy metals (Olayiwola et al., 2017).

Pollution indices are a powerful tool for environmental quality assessment. The commonly used pollution indices for heavy metals in soils are classified into two types, single and integrated pollution index (Yuan et al., 2004, Qingjie et al., 2008; Hafizur Rahman et al., 2012). In the present study, two single indices, namely index of contamination factor (CF) and ecological risk factor (Er), as well as two integrated indices potential ecological risk index (PRI) and pollution load index were used to evaluate the level of heavy metal pollution around Kano municipal solid waste dumpsite. There have been a number of studies which reported the physico-chemical characteristics and concentration of heavy metals in soil around the vicinity of dumpsites in Kano Metropolis (Karkarna and Mujahid, 2020, Ali, 2017, Koki and Jimoh, 2013 and Sabo and Jimoh, 2013). But, none of the studies attempt to evaluate the level of heavy metal pollution using single and integrated pollution index. Therefore the objectives of the present study were (1) to determine contents of $\mathrm{Zn}, \mathrm{Pb}, \mathrm{Cd}$, $\mathrm{Cr}$ and $\mathrm{Ni}$ in soils of municipal solid waste dumpsites; (2) to determine the level of heavy metals pollution using single indices (contamination factor and ecological risk factor and integrated pollution indices which include (potential ecological risk index (PERI) and pollution load index (PLI). 


\section{MATERIALS AND METHODS}

\section{Study Area}

The metropolitan city of Kano is the largest urban setting in northern Nigeria and only second to Lagos in the whole country. It is known for a wide range of industrial and commercial activities (Maconachie, 2007). It consists of 8 local government areas with a total population of approximately 4 million. The metropolis spreads across an area of about $500 \mathrm{~km} 2$ located between longitude $8^{\circ}$ and $9^{\circ}$ east and latitude $10^{\circ}$ and $12^{\circ}$ north (Ahmed et al., 2013). Kano falls within the Sudan savannah vegetation zone enjoying the warm tropical climatic condition of Western Africa. It is positioned in the northern central boundary of Nigeria at about $840 \mathrm{~km}$ away from the beginning of Sahara desert and about 1,140km away from the coast of Atlantic Ocean (Okunola et al., 2012)

The research instruments used include GPS for recording the coordinate, soil auger used for taking the soil sample, measuring tape used for measuring the soil depth, Kjiedal digestion set apparatus and Atomic absorption spectrophotometer were used to analyze the concentration of heavy metals under investigation

\section{Soil Collection and Sampling}

Forty two soil samples were collected from seven municipal solid waste dumpsites of Kano metropolis using circular plot method. In each dumpsite, three point's soil samples were collected from the depth ( 1 1, S2 and S3). At each point, two soil samples were collected from the depth of $0-15 \mathrm{~cm}$ and $15-30 \mathrm{~cm}$. Each soil sample was composed of 2 sub-samples collected around the corresponding sampling point, and all the sampling coordinates were recorded by portable GPS. The samples were carefully handled right from the field to the end of the laboratory analysis to avoid contamination. Figure 1 shows soil sampling points in each of the seven dumpsites

\section{Soil Preparation and Analysis}

The soils were air dried for three days, ground and sieved through a $2 \mathrm{~mm}$ sieve. These were stored in labelled polythene bags and were taken to the laboratory for analysis. After which, $1.25 \mathrm{~g}$ of each sample was digested with $20 \mathrm{~mL}$ aqua regia $\left(\mathrm{HCl} / \mathrm{HNO}_{3} 3: 1\right)$ in a beaker (open-beaker digestion) on a thermostatically controlled hot plate. The digest were heated to near dryness and cooled to ambient temperature. Then $5.0 \mathrm{~mL}$ of hydrogen peroxide was added in parts to complete the digestion and the resulting mixture heated again to near dryness in a fume cupboard. The beaker walls were washed with $10 \mathrm{~mL}$ of deionised water and $5 \mathrm{~mL} \mathrm{HCl}$ were added, mixed and heated again. The resulting digest was allowed to cool and transferred into a $50 \mathrm{~mL}$ standard flask and made up to the mark with de-ionised water. $\mathrm{Pb}, \mathrm{Cd}, \mathrm{Ni}, \mathrm{Zn}$, and $\mathrm{Cr}$ heavy metal elements were then analyzed by direct aspiration of the sample solution into a PerkinElmer model 2380 flame atomic absorption spectrophotometer (AAS).

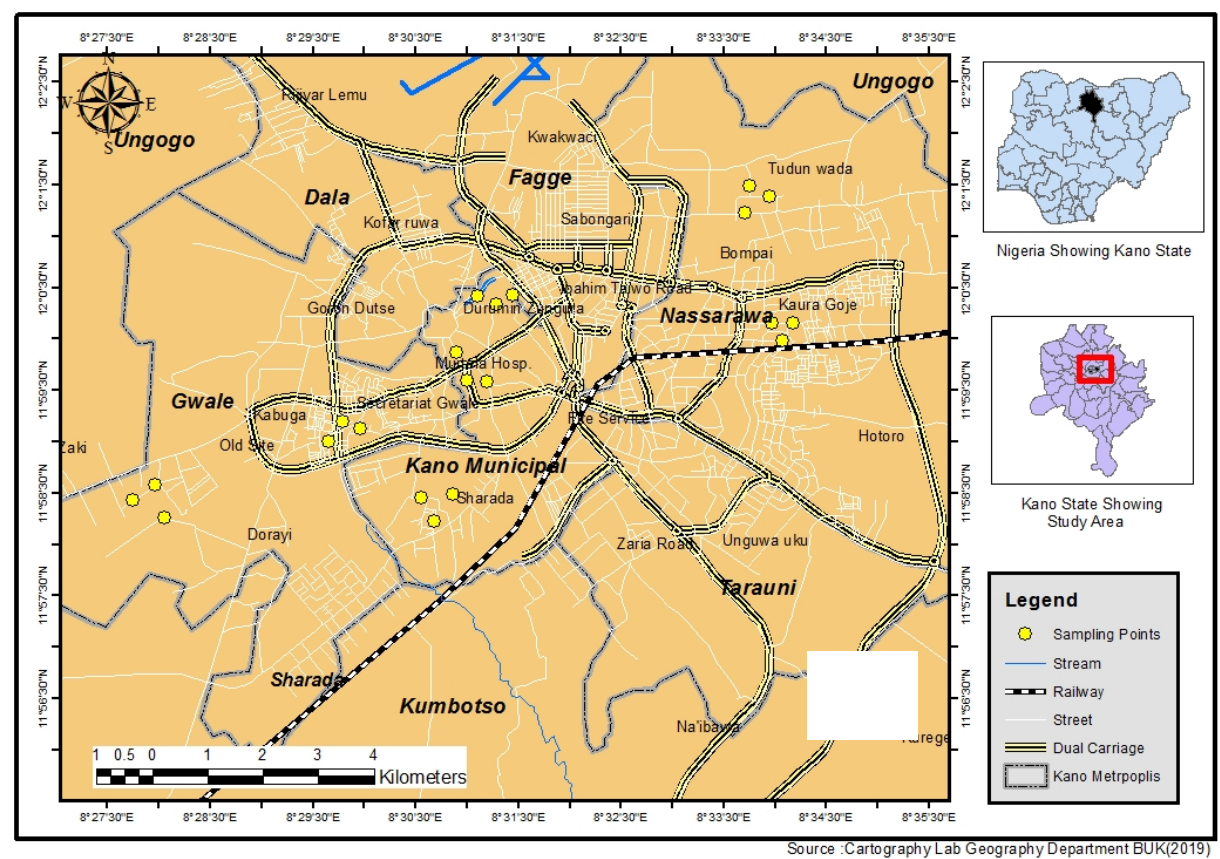

Figure Figue1: View of Kano Metropolis Showing the Sampling Locations 


\section{STATISTICAL ANALYSIS}

Data were analyzed using SPSS software (version 23) and micro soft Excel 2007. Descriptive statistics were conducted to determine the mean of investigated heavy metals in soil samples. The single pollution indices (contamination factor and ecological risk) and integrated pollution index (PLI and potential ecological risk) were analyzed using descriptive statistics in which data were presented in mean and table.

Assessment of heavy metals pollution

In this study, the assessment of soil pollution was conducted using the two single indices, namely index of contamination factor (CF) and ecological risk factor (Er), as well as two integrated indices such as pollution load indices and potential ecological risk index (PRI).

\section{SINGLE INDICES POLLUTION}

1. Contamination Factor $(\mathrm{Cf})$ is the ratio of the concentration of each metal $(\mathrm{Ci})$ to the background or reference value (Cri). Where $\mathrm{C} i$ is the mean concentration of each of the investigated metal in soil or sediment drawn from at least five sampling sites and Cri is the background value of the metal. In order to unify the assessment results, reference values as provided by
Department of Petroleum Resources threshold value ( DPR ) 2002 were used as background values $(\mathrm{Cr}=100, \mathrm{Ni}=35, \mathrm{Zn}$ $=140, \mathrm{Cd}=0.88$ and $\mathrm{Pb}=85)$. The following terminology was used for the pollution index model: $\mathrm{PI}<1$, non-pollution; $1 \leq \mathrm{PI}<$ 2 , low level pollution; $2 \leq \mathrm{PI}<3$, moderate level of pollution; $3 \leq \mathrm{PI}<5$, strong level of pollution; $\mathrm{PI} \geq 5$, very strong level of pollution (Yang et al., 2011).

2. Ecological risk index (Er):-This is an index that quantitatively expresses the potential ecological risk associated with a given single contaminant Hakanson (1980). Calculated as follows:

$$
\mathrm{Er}=\mathrm{Tf} \times \mathrm{Cf} \text {...................... (Equation 1); }
$$

Where, $T f$ is the toxic-response factor of an element, and $\mathrm{Cf}$ is the contamination factor. Five terminologies are used to define ecological risks based on Hakanson (1980). These are < 40, low potential ecological risk; $40<80$, moderate potential ecological risk; $80<160$, considerable potential ecological risk; $160<320$, high potential ecological risk; and $\geq 320$, very high ecological risk.

Table 1 Toxic Response factor for studied heavy Metals ( $\mathrm{Zn}, \mathrm{Pb}, \mathrm{Cd}, \mathrm{Cr}$ and $\mathrm{Ni}$ )

\begin{tabular}{lcc}
\hline S/No. & Element & Toxic Response Factor \\
\hline 1 & Zinc & 1.0 \\
2 & Lead & 5.0 \\
3 & Cadmium & 30 \\
4 & Chromium & 2.0 \\
5 & Nickel & 5.0 \\
\hline
\end{tabular}

Adopted by Hakanson (1980)

\section{INTEGRATED POLLUTION INDICES}

1. Potential ecological risk index (PERI)

Potential ecological risk index (PERI):-This index is the sum of all the ecological risk factors of the metals under study, taking into account the cumulative effects of the metals under study (Hakanson, 1980). It is calculated thus:

$\sum R I=($ ErF1 + ErF2 + ErF3....ErFn).........................Equation

Where, ErF is the ecological risk factor and $n$ is the number of elements studied.

The following terminologies have been used for the potential ecological risk index (Hakanson, 1980): < 150, low ecological risk; $150<300$, moderate ecological risk; $300<600$, considerable ecological risk; and $\geq 600$, very high ecological risk. This method comprehensively considers the synergy, toxic level, concentration of the heavy metals and ecological sensitivity of heavy metals. PERI is formed by three basic modules: degree of contamination $(\mathrm{Cd})$, toxic-response factor $(\mathrm{Tr})$ and ecological risk factor (Er) (Jiang, 2014).

\section{Pollution load index}

The number of times the metal concentration in the sampled soil exceeded the average natural background concentration is indicated by the PLI value and it reveals the total comprehensive degree of heavy metal toxicity in a given sample (Ololade, 2014). Pollution load index is an example of root of the product of pollution index indices which is based on contamination factor of each metal in soil. This aspect of integrated pollution indices have been used to quantify pollution load of heavy metals in both soils and sediments. 
The model also provides an easy and comprehensive means of assessing the quality of an investigated site (Waheshi et al., 2017; Goher et al., 2014). Where PLI is pollution load index of individual metal described earlier and $\mathrm{n}$ is the number of investigated metals.

$\mathrm{PLI}=\sqrt{C F 1} \times C F 2 \times C F 3 \ldots \ldots . . . \mathrm{CFn}^{1 / \mathrm{n}}$...Equation

\section{RESULTS AND DISCUSSION}

The mean concentrations of heavy metals in the soil samples are shown in Table 2 . The data revealed that all the analyzed metals accumulated by the soil in two different depth of top soil $(0-15 \mathrm{~cm})$ and sub soil (15-30) $\mathrm{cm}$.

Table 2 Mean Concentration of Heavy Metals in Comparison with EU and DPR (2002) Standard

\begin{tabular}{llccc}
\hline Element & $\begin{array}{c}\text { Top soil (0-15) } \\
\mathbf{c m}\end{array}$ & $\begin{array}{c}\text { Sub-surface } \\
(\mathbf{1 5 - 3 0 )} \mathbf{~ c m}\end{array}$ & $\begin{array}{c}\text { EU (2002) } \\
\text { Standard. }\end{array}$ & $\begin{array}{c}\text { D.P.R(2002) } \\
\text { Standard }\end{array}$ \\
\hline $\mathrm{Zn}$ & 0.30 & 0.50 & 300 & 140 \\
$\mathrm{~Pb}$ & 1.71 & 7.71 & 300 & 85 \\
$\mathrm{Cd}$ & 0.012 & 0.025 & 3.0 & 0.88 \\
$\mathrm{Cr}$ & 0.27 & 0.31 & 100 & 100 \\
$\mathrm{Ni}$ & 0.49 & 0.45 & 75 & 35 \\
& & & & \\
\hline
\end{tabular}

Sources: Laboratory Analysis (2019) and EU and DPR (2002) Standard

The mean concentration of zinc $(\mathrm{Zn})$ was in the range of $0.30-0.50 \mathrm{mg} / \mathrm{kg}$. The lowest zinc content $(0.30 \mathrm{mg} / \mathrm{kg})$ was obtained at $(0-15 \mathrm{~cm})$ depth and the highest $(0.50 \mathrm{mg} / \mathrm{kg})$ was recorded from the depth $(15-30 \mathrm{~cm})$. The results of this study were slightly lower as compared to a study by Lawan et al., (2012) on vertical migration of heavy metals in dumpsite soil at Maiduguri Metropolis dumpsite, Nigeria that reported mean zinc concentration at $1.80 \pm$ $0.01 \mathrm{mg} / \mathrm{kg}$. It is clearly noticed that $\mathrm{Zn}$ concentration in all the dumpsites was much lower than maximum allowable limit of European Union standard (2002). The chief pollution sources of $\mathrm{Zn}$ in soils are metalliferous mining activities, agricultural use of sewage sludge and the use of agro-chemicals such as fertilizers and pesticides. Large concentrations of $\mathrm{Zn}$ in the soil have adverse effects on crops, livestock and human (Parth et al., 2011).

As indicted in Table 2, the mean concentration of lead was $(7.71 \mathrm{mg} / \mathrm{kg}) 15-30 \mathrm{~cm}$ depth while for the $0-15 \mathrm{~cm}$ depth the mean lead concentration was recorded as $(1.77$ $\mathrm{mg} / \mathrm{kg}$ ). The concentration of lead values in the dumpsites of Kano metropolis was far lower than 24.70-54.20 mg kg-1 reported by Akinbile, (2012) for land fill site at Akure, Nigeria. Parth et al., (2011) also reported 42.90-1833.50 mg $\mathrm{kg}-1$ lead in soil waste disposal sites in Hyderabad city, India. The $\mathrm{Pb}$ concentrations in all the dumpsites were within recommended threshold by European Union (2002) standard. However, (Awokunmi et al., 2010) reported very high levels of lead in soils collected from various dumpsites located at Ikere and Ado Ekiti Metropolis, South Western Nigeria ranging between $3500-6860 \mathrm{mg} / \mathrm{kg}$.
The concentration of cadmium was found in trace amount for the seven dumping sites withthe highest mean $(0.025 \mathrm{mg} / \mathrm{kg})$ occurring at the depth of $15-30 \mathrm{~cm}$ while lowest values was found at depth of $(0-15 \mathrm{~cm})$ with concentration value of $(0.012 \mathrm{mg} / \mathrm{kg})$. This was different with the work reported by (Azeez et al., 2013; Olarinoye et al., 2009) whose cadmium concentration was found in the range of 0.003 to 0.006 . Naturally occurring cadmium concentration ranges from 0.03 to $0.30 \mu g g-1$. Cadmium concentrations in the soils analyzed were found within the naturally occurring range. This is pollution especially when cadmium is known to be one of the most harmful pollutants, though cadmium was not detected in some of the soil samples analyzed. As per results from Table 2, the level of $\mathrm{Cr}$ content in different sampling area was ranged from 0.274 at depth $(0-15 \mathrm{~cm})$ to $0.31 \mathrm{mg} / \mathrm{kg}$ $(15-30 \mathrm{~cm})$.Chromium concentration was higher than the results reported by (Amos, Bamidele, Onigbinde, 2013) for similar study at Yenagoa in Nigeria in which maximum concentration of chromium was found to be $(0.005 \mathrm{mg} / \mathrm{kg})$. Sources of $\mathrm{Cr}$ in the soils could be due to waste consisting of lead chromium batteries, coloured polythene bags, discarded plastic materials and empty paint containers (Jung et al., 2006).

The result of Nickel concentration as showed in the table 2 revealed that the mean concentration of $\mathrm{Ni}$ in soils at depth of soil (0$15 \mathrm{~cm}$ ) was $0.49 \mathrm{mg} / \mathrm{kg}$ while lowest mean concentration $(0.45 \mathrm{mg} / \mathrm{kg})$ was found at a depth of $(15-30 \mathrm{~cm})$. Nickel concentrations in soils at both waste dumping sites were also lower compared to similar study at Kenya, Kadhodeki municipal solid waste dumping sites (17.44 mg/kg) (Murugi, 2009). 
The $\mathrm{Ni}$ concentration in this study was comparatively higher than $(0.222 \mathrm{mg} / \mathrm{kg})$ reported by Onu et al (2021) for similar study in a farmland near market dumpsite in Zaria, Nigeria.

Contamination factor and pollution load index of the soils in the Study Area

The result of Contamination factor (Cf) in Table 3 indicated that all of the heavy metals in the surface and surface soils were in the class of very slightly contamination. The $\mathrm{Cf}$ values recorded for surface soils $(0-15 \mathrm{~cm})$ ranged between 0.002-0.02 while for sub-surface soils the contamination factor (Cf) values ranged from (0.003-0.02). The result of contamination factor is in dis-agreement with the work of Shittu et al., (2018) who reported higher contamination of heavy metals and pollution load index at Ilokun dumpsite, Ado Eki, Nigeria. Similarly, Elias et al (2011) reported low contamination for $\mathrm{Cd}, \mathrm{Zn}$ and $\mathrm{Cr}$ at dumpsite in Lagos Mainland Area. However, the levels of contamination factor obtained in the present study were lower than those reported by Ogunmodede et al., 2017 (0.47-11.78) in SouthWest Nigeria.

Table 3 shows the summary of pollution load index value in the five studied heavy metals ( $\mathrm{Zn}, \mathrm{Pb}, \mathrm{Cd}, \mathrm{Cr}$ and $\mathrm{Ni}$ ) which indicates that there is minimal pollution load in the study sites (PLI less than 1). The Results of pollution load index obtained in the present study were lower with the work of Ikpe et al (2018) who reported $\mathrm{PLI}$ ranged between $(1.83-8.26)$ in soils of three auto mechanic villages in Abuja. Also, the result of the pollution load index were also lower than value reported by Yahaya et al. (2021) in contaminated soils of three mining villages in Zamfara State, Nigeria.

Table 3 Contamination factor and Pollution load index of soils in the study area

\begin{tabular}{lllllll}
\hline Parameters & Zn & Pb & Cd & Cr & Ni & PLI \\
\hline Mean (0-15) & 0.30 & 1.71 & 0.012 & 0.27 & 0.49 & \\
DPR (2002) & 140 & 85 & 0.88 & 100 & 35 & \\
Cf $(0-15)$ & 0.002 & 0.02 & 0.01 & 0.0027 & 0.01 & $2 \times 10^{11}$ \\
Mean(15- & 0.50 & 7.71 & 0.025 & 0.31 & 0.45 & \\
30) & 0.003 & 0.09 & 0.02 & 0.0031 & 0.01 & $3 \times 10^{10}$
\end{tabular}

Wf (15-30) Resources (2002) standard

Ecological risk Factor and potential ecological Risk of the soil in the Study Area

Table 4 shows the results of ecological risk factor and potential ecological risk index (PERI). The mean value of the ecological risk factor $(\mathrm{Er})$ ranged from 0.0054 to 0.30 for surface soil $(0-15) \mathrm{cm}$ while sub-surface soil, the value of ecological risk factor ranged from 0.005 to 0.6 .It was found that ecological risk factors for $\mathrm{Zn}, \mathrm{Pb}, \mathrm{Cd}, \mathrm{Cr}$, and $\mathrm{Ni}$ were below 1.0, thus indicating low ecological risk.

Table 4 Ecological risk Factor and potential ecological Risk in the Study Area

\begin{tabular}{lllllll}
\hline Parameters & Zn & Pb & Cd & Cr & Ni & RI \\
\hline Tf & 1.0 & 5.0 & 30 & 2.0 & 5.0 & \\
Er (0-15) & 0.002 & 0.1 & 0.3 & 0.0054 & 0.07 & 0.41 \\
Er(15-15) & 0.002 & 0.045 & 0.6 & 0.0050 & 0.05 & 0.61 \\
\hline
\end{tabular}

WhereTf stand for toxic Response factor, Er, ecological risk factor and RI, Potential ecological Risk (PERI)

The values of ecological risk factor (Er) obtained in the present study were similar with the work of Yahaya et al (2021) in contaminated soils of three mining villages in Zamfara State, Nigeria. Similarly, Jinal et al (2017) in Nashik District, India reported the higher value of potential ecological risk index of (146.5-307.0) which was far lower than values obtained in the present study.

\section{CONCLUSION}

The present paper aims to evaluate soil contamination with metals using single and integrated pollution indices in Soils around Municipal solid waste dumpsites of Kano Metropolis, Kano state, Nigeria. The concentration of the studied heavy metals $(\mathrm{Zn}, \mathrm{Pb}, \mathrm{Cr}$, $\mathrm{Ni}$ and $\mathrm{Cd}$ ) were far below the maximum tolerable levels set by European Union (EU, 2002) standard for heavy metal in soil. 
The results of single pollution index shows that Contamination factor and ecological risk in the seven dumpsites were in the class of low contamination. The values of integrated pollution index in the studied dumpsites revealed that the potential ecological risk index (PERI) and pollution load index for five studied metals were found in the range of low contamination. It is therefore recommended,

\section{REFERENCES}

Agber, P.I., A. Ali, and N.A. Isaku. (2013). Assessment of groundwater quality, soil properties and nutrient content of soil in areas close to municipal refuse dumpsites in Markudi, Nigeria. J. Biol. Chem. Res. 30(1): 88-97.

Ahmed, M., Muhammad, N., Mohammed, M. U. and Idris Y. (2013). A GIS-Based Analysis of Police Stations Distributions in Kano Metropolis. IOSR Journal of Computer Engineering. ISSN: 2278-0661, ISBN: 22788727Vol 8, Issue 4, PP 72-78. www.iosrjournals.or

Akinbile, C.O. (2012). Environmental impact of landfill on groundwater quality and agricultural soils in Nigeria. Soil Water Res. $7(1): 18-26$.

Ali. A.F, Young R.J. and A. I. Tanko. A.I (2017). Distribution of Dumpsites as a Threat to Sustainable Urban Environment in Nigeria. Proceedings Sardinia 2015, Fifteenth International Waste Management and Landfill Symposium S. Margherita di Pula, Cagliari, Italy.

Amos, T., Bamidele, M. W., Onigbinde, A., (2013) "Assessment of some heavy metals and physicochemical properties in surface soils of municipal open waste dumpsite in Yenagoa, Nigeria," A. J. Environ. Sci. and Tech., 41-47.

Azeez, J.O., Hassan, O.A.and.Egunjobi,P.O (2011). Soil contamination at dumpsites: Implication of soil heavy metals distribution in municipal solid waste disposal system: A case study of Abeokuta, Southwester Nigeria' Soil Sediment Contam. 20(4):370386.

Awokunmi,E.E., Asaolu,S.S., Ipinmoroti, K.O.(2010). Effect of leaching on heavy metals concentration of soil in some dumpsites. African Journal of Environmental Science and Technology 4(8):495-49

Department of Petroleum Resources (DPR), 2002: Environmental guidelines and standards for the petroleum industries in Nigeria (revised edition). Departmentof Petroleum Resources, Ministry of Petroleum and Mineral Resources, Abuja, Nigeria.

Dirisu, C.E, Biose,E.and Aighewi, I.T (2019); Heavy metal contamination of Ewhare Dumpsite Environment in Nigeria s Niger Delte.

UMYU Journal of Microbiology Research the regulation and legislation on environmental issues, including effective solid waste management strategies and enforcement of emission standards should be emphasized in order to reduce the illegal dumping of waste which lead accumulation of heavy metals on the urban dumping sites of developing countries.

SCIREA Journal of Environment, Volume 3 , issue 2

Elias, Peter, Gbadegesin, Adeniyi (2011): Spatial Relationships of Urban Land Use, Soils and Heavy Metal Concentrations in Lagos Mainland Area.J. Appl. Sci. Environ. Manage. Vol. 15 (2) 391 - 399.

European Union (2002) Heavy Metals in Wastes, European Commission on Environment. http://ec.europa.eu/environment/ waste/studies/pdf/heavymetalsreport.pdf

Goher ME, Farhat HI, Abdo MH, Salem SG (2014). Metal pollution assessment in the surface sediment of Lake Nasser, Egypt'. Egyptian Journal of Aquatic Research 40:213-224

Hafizur Rahman S, Khanam D, Mehedi Adyel T, Shahidul Islam M, Aminul Ahsan M, Akbor A (2012) Assessment of heavy metal contamination of agricultural soil around Dhaka export processing zone (DEPZ), Bangladesh: implication of seasonal variation and indices. Appl Sci 2:584-601. https: //doi.org/10.3390/app2030584

Hakanson L (1980) An ecological risk index for aquatic pollution control. Sedimentol Approach Water Res 14(8):975-1001

Isa, Koki and Jimoh, W. L. O.(2013) Determination of heavy metals in soils from dump site of tanneries and farmlands in challawa industrial estate KANO, NIGERIA.Bayero Journal of Pure and Applied Sciences, 6(2): 57 64.http://dx.doi.org/10.4314/bajopas.v6i2. 13

Ikpe, N.C, Kenechukwu, E.C, and Ikechukwu,E.C. (2018)Use of integrated pollution indices in assessing heavy metals pollution in soils of three auto mechanic villages in Abuja. African Journal of Environmental Science and Technology, Vol. 12(10), pp. 370-376

Jiang X., Lu W. X., Zhao H. Q., Yang Q. C., and Yang Z. P. (2014). Potential ecological risk assessment and prediction of soil heavymetal pollution around coal gangue dump, Nat. Hazards Earth Syst. Sci., 14: 15991610, DOI: 10.5194/nhess-14-1599.

Jimoh, W.L.O. and Sabo, Y.( 2013); Sequential Analysis of metals in municipal dumpsite composts of kano metropolis, nigeria.Bayero Journal of Pure and Applied Sciences, $6(1): \quad 87 \quad-\quad 91$. http://dx.doi.org/10.4314/bajopas.v6i1.18 
Jinal, L., Esha ,T., and Sulekha, G.(2017) :Assessment of metal Contamination using Single and Integrated pollution Indices in soil samples of Nashik District, India International Journal of Development Research Vol. 07, Issue, 09, pp.1501615024,

Jung, C.H., T. Matsuto and N. Tanaka. (2006). Flow analysis of metals in a municipal solid waste management system. Waste Manage. 26:1337-1348

Karkarna,M.Z., and Matazu,M.A,(2020): Heavy Metal spatial variability among Dumpsites Kano Metropolis, Nigeria, FUDMA Journal of Pure and Applied Sciences, Volume 7 No.1. 260-270.

Karkarna,M.Z., $\quad$ and Matazu,M.A,(2021): Assessment of Heavy Metal contamination in Surface and Sub-surface soil from Dumpsite in Kano Metropolis, Nigeria, Dutse Journal of Pure and Applied Sciences, Volume 7 No.1. 260-270.

Lawan, I. Bukar., Stephen, S. H., Goni, A. D., Tijjani, M.(2012), "Study of vertical migration of heavy metals in dumpsites soil ARPN," J. of Sci. and Tech. ISSN, 22257217, 50,

Maconachie, R. (2007). Urban growth and land degradation in developing cities: change and challenges in Kano, Nigeria. Aldershot, UK. Ashgate Publishing

Murugi, J. N., (2009). Assessment of heavy metal concentration in the Environment and perceived health risks by the community around Kadhodeki dumpsite, NairobiCounty," Degree of doctor of philosophy, in the school of public health of Kenyatta University, Nairobi.

Ogunmodede, O.T,Ojo,A,A, Jegede, R.O,(2016) Evaluation of pollution loads in and around Municipal solid waste Dumpsites, World Applied Sciences Journal 34(6):720-732

Okunola, O. J., Uzairu, A., Gimba C. E. and Ndukwe, G. I. (2012), Assessment of Gaseous Pollutant along High Traffic Roads in Kano, Nigeria.International Journal of Environment and Sustainability, 1(1), pp 115

Olarinoye, I. O., I. Sharifat, and M. T. Kolo. (2009). Heavy metal content of soil samples from two major dumpsites in Minna. Nat. Appl. Sci. J. 11:1.

Ololade I. A.,(2014) "An assessment of heavy metal contamination in soils within automechanic workshops using enrichment and contamination factors with geoaccumulation indexes," Journal of Environmental Protection, vol. 5, pp. 970982,

Onue.E., James, I.U, Anas, A.S, Aliyu, M.,Bulus. M,(2021): Assessment of heavy metals contamination in a farmland near a Market Dumpsite in Zaria, Nigeria, Dutse Journal of

UMYU Journal of Microbiology Research
Pure and Applied sciences, Volume7, No 1, page:271-279

Partha, V., Murthya, N.N., Saxena, P.R. (2011).Assessment of heavy metal contamination in soil around hazardous waste disposal sites in Hyderabad city (India): natural and anthropogenic implications. E3. J. Environ. Res. Manage. 2 (2): 27-34.

Proshad R, Ahmed S, Rahman M, Kumar T. (2017). Apportionment of hazardous elements in agricultural soils around the vicinity of brick kiln in Bangladesh. Journal of Environmental and Analytical Toxicology. 7: 439.

Pradhan, J. K., \& Kumar, S. (2014). Informal ewaste recycling: Environmental risk assessment of heavy metal contamination in Mandoli industrial area, Delhi, India. Environmental Science and Pollution Research, 21(13), 7913-7928. doi:10.1007/s11356-014-2713-2

Qingjie G, Deng J, Xiang Y, Wang Q, Yang L (2008) Calculating pollution indices by heavy metals in ecological geochemistry assessment and a case study in parks of Beijing. J China UnivGeosci 19(3):230-241

Shittu, O. S. Ayodele,O. J. Augustus O. A. Ilori, Abidemi O. Filani, Adetola T. Afuye (2018). Heavy Metal Contamination of a Dumpsite Environment as Assessed with Pollution Indices. World Academy of Science, Engineering and Technology,International Journal of Agricultural and Biosystems Engineering Vol:12, No:1,

Un-habitat (2008). The State of African Cities. A Frame Work for Addressing Urban Challenges in Africa. United Nations HumanSettlement Programme.

Waheshi YAA, El-Gammal MI, Ibrahim M, Okbah MAA (2017). Distribution and Assessment of Heavy Metal Levels using Geoaccumulation Index and Pollution Load Index in Lake, Edku Sediments Egypt. International Journal of Environmental Monitoring and Analysis 1:1-8.

Yahaya,S.M, Abubakar,F. Abdu,N(2020). Ecological risk assessment of heavy metalcontaminated soils of selected villages in Zamfara State, Nigeria.SN Applied Sciences (2021) 3:168 । https: / /doi.org/10.1007/s42452-021-041756

Yang ZP, Lu WX, Long YQ, Bao XH, Yang QC (2011). Assessment of heavy metal contamination in urban top soils from Chagchun City,China. Journal of Geochemical Exploration 108:27-38.

Yuan C, Shi J, He B, Liu J, Liang L, Jiang G (2004) Speciation of heavy metals in marine sediments from the East China Sea by ICPMS with sequential extraction. Environ Int 30:769-783 